\title{
The face and the faceness: Iconicity in the early faciasemiotics of Paul Ekman, 1957-1978
}

\author{
Devon Schiller ${ }^{1}$
}

\begin{abstract}
Paul Ekman is an American psychologist who pioneered the study of facial behaviour. Bringing together disciplinary history, life study, and history of science, this paper focuses on Ekman's early research during the twenty-year period between 1957 and 1978. I explicate the historical development of Ekman's semiotic model of facial behaviour, tracing the thread of iconicity through his life and works: from the iconic coding of rapid signs; through the eventual turn from classifying modes of iconic signification using gestalt categories to classifying modes of producing iconic sign-functions using minimal units; to the role and importance of iconicity for the study of the facial expression of emotion, both in terms of the similarities between iconic and analogue signs as well as the differences between facial coding and linguistic signification. In this intellectual genealogy, I argue not only that Ekman relied extensively upon conceptualizations and terminologies from semiotic thought for the creation of the Facial Action Coding System (FACS), but also that the question of iconicity is the pivotal problem across the many discoveries and innovations in what I term 'Ekmanian faciasemiotics'.
\end{abstract}

Keywords: Basic Emotions Theory (BET); Facial Action Coding System (FACS); facial expression; iconicity; nonverbal behaviour; Paul Ekman; psychology; semiotics of the face

\section{Introduction}

Paul Ekman is an American psychologist born in 1934 who pioneered the study of facial behaviour. He is best known for his seminal work doing pan-cultural research on the facial expression of emotion, Basic Emotions Theory (BET), deception detection, and micro-expressions, as well as for creating the Facial Action Coding System (FACS). Although Ekman identifies himself as a psychologist, and not a

\footnotetext{
1 Department of English and American Studies, University of Vienna, Vienna, Austria; e-mail: devonschiller@gmail.com. This research was supported by a DOC Fellowship from the Austrian Academy of Sciences.
} 
semiotician, a review of the literature reveals that his science was heavily influenced by semiotics. As Ekman (1982: 86fn2) writes, "over the years, [he] proposed a number of different phrases" to distinguish his approach to facial expression and its dynamic movement, but hopes that "terms, taken from semiotics, allow a more lucid differentiation". In his autobiography, Ekman (2016: 11, 40, 41) also recalls the ways in which his collaborations and critiques with various "intellectual fathers," each of whom brought semiotic frameworks into their methodological approaches, came about through "a string of coincidences" and "good luck". And by the late 1960s, Ekman (1982: 45) began to explicitly model facial behaviour as "a multimessage, multisignal semiotic system".

Bringing together disciplinary history, life study, and history of science, this paper focuses on Ekman's early research during the twenty-year period between 1957 and 1978. The extent to which Ekman's natural science of nonverbal behaviour, especially in its formative years, was informed and inspired by semiotic theories and thinkers has been largely overlooked in the histories of this science (Plamper 2015: 142-172; Leys 2017: 76-128), which tend to fixate on later debates between biological essentialist and social constructivist positions. The importance of semiotics for Ekman and his measurement techniques has even been widely neglected in the semiotic literature, from general encyclopedia (Bouissac 2007[1998]) and handbooks (Grammer 2004: 3451-3452) to specialized monographs (Berson 2015: 113-115), where Ekman receives passing but persistent citation. In this paper, I seek neither to advocate nor oppose what Maria Gendron and Lisa Feldman (2017: 24) characterize as Ekman's "'neuro-cultural' theory" for the facial expression of emotion, but instead to reframe his research within the context and history of the discipline of semiotics. I explore how Ekman referenced semiotic works by Jurgen Ruesch as well as Charles W. Morris in his semiotic model of facial behaviour, entered the discipline of semiotics through his friendship with Thomas A. Sebeok, and was further inspired by David Efron, among others.

For this intellectual genealogy, I draw from primary sources that include Ekman's autobiographical writings, professional correspondence, and scientific research, contextualizing his statements with relevant confirmations, criticisms, and confusions, and comparing his semiotics to Peircean as well as Saussurean traditions. Across the three sections of this paper, I explicate the historical development of Ekman's semiotic model, tracing the thread of iconicity through his life and works: from the iconic coding of rapid signs; through the eventual turn from classifying modes of iconic signification using gestalt categories to classifying modes of producing iconic sign-functions using minimal units; to the role and importance of iconicity for the study of the facial expression of emotion, both in terms of the similarities between iconic and analogue signs as 
well as the differences between facial coding and linguistic signification. With this historicization of a theorization, I argue not only that Ekman relied extensively upon conceptualizations and terminologies from semiotic thought for the creation of FACS, but also that the question of iconicity, rather than stereotypicality or universality, is the pivotal problem across the many discoveries and innovations of what I term 'Ekmanian faciasemiotics'.

\section{The quest for facial iconicity begins}

Ekman got his start in semiotics during graduate school in the 1950s. He obtained his doctorate in clinical psychology from Adelphi College on Long Island in New York in 1958, at the time the only programme that trained psychotherapists, but which later would become the first university-based professional school of psychology in the United States. Before he graduated, Ekman was required to complete a one-year clinical internship. He pursued this internship under Swissborn American psychiatrist Jurgen Ruesch at the Langley Porter Neuropsychiatric Institute, a part of the University of California San Francisco Medical Center which, founded in 1941, was the first psychiatric institute in California. Ekman chose Langley Porter because Ruesch had written Communication: The Social Matrix of Psychiatry with English anthropologist Gregory Bateson in 1951 and Nonverbal Communication Notes on the Visual Perception of Human Relations with American painter and poet Weldon Kees in 1956. Ekman (2016: 14) writes in his autobiography that he had drafted an unpublished review of Nonverbal Communication "praising the many interesting ideas but criticizing it for a total lack of data, or even examples". The critique was valid, at least from a methodological perspective, and considering that Ekman had been "trained in research methods" by American psychologist Robert Berryman, "a Skinnerian” who did operant conditioning studies and had "an explicit bias against theory not grounded in direct observation" (Ekman 2016: 95). By the late 1950s, Ruesch went further and put forward a semiotic model of nonverbal behaviour in his "Principles of human communication", published the same year Ekman applied for an internship in 1957, and republished in Semiotic Approaches to Human Relations in 1972. As Winfried Nöth (1990: 169) points out, "the title of Ruesch's collection of earlier papers" indicates how scientific research on nonverbal behaviour, "which was first developed within communication theory, was later placed within the framework of a semiotic theory".

However, Ekman's acquaintance with Ruesch's communication-turned-semiotic approach to nonverbal behaviour started even before this internship. In his first 
published article, written during the third year of his doctoral studies, Ekman (1957: 141) cites Ruesch in his own classification of interindividual behaviour into three modal types, including the "verbal, vocal, and nonverbal" which, he claims, "can be distinguished in terms of the medium of expression, the manner in which they are perceived, their developmental sequence, and their communicative value". Further, Ekman (1957: 141) argues that "[a]ll three forms of behavior have both consensually validated linguistic or symbolic meaning, and more private or autistic connotations," but that "[v]erbal far exceeds vocal or nonverbal behavior in degree of codification and consequent symbolic use". In this way, Ekman (1957: 141) introduces an idea like iconicity, although he does not call it this, by situating nonverbal behaviours "less defined as to their meaning or intent" in opposition to verbal and vocal behaviours that "achieve definite symbolic usage". Looking back with hindsight, Ekman (2016: 3) believes the paper "did not merit" publication in The Journal of Psychology. Still, Ekman's first publication illustrates how the face reader as a young man, from the very outset of his 'faciasemiotic project', was investigating the complexity as well as the continuity between iconic, indexical, and symbolic relations.

The same year that Ekman began his internship, Ruesch (1972: 127) defines "communication" in the broadest sense to include "all of the procedures by which one mind may affect another". According to Ruesch (1972: 127), communication "involves not only oral or written speech", but also the performance and pictorial arts, "and in fact, all human behavior". Ruesch (1972: 127) triadically models the relationship between these signs and their object: signs constitute "a circumscript part of an action or event which either by force of its own structure or because of attention paid to it possesses for an observer problem-solving properties or cue values"; signals constitute "an impulse in transit regardless of whether it circulates inside or outside a human organism"; and symbols constitute "an extraorganismic device which has been agreed upon to refer in a condensed way to a series of actions or events [...] used for coding purposes in order to transmit messages". While all such processes of communication "exert an organizing influence" upon constituent individuals and "weld them into a larger system" (Ruesch 1972: 128). Therefore, to Ruesch (1972: 128), messages are "purposive expressions of internal events with the intent to convey information to other persons" that have also "been perceived and interpreted by another person". As Ruesch (1972: 128) claims, the "communication apparatus of man", which is sheltered within his body, carries messages through "effector organs, the sender", the "evaluative apparatus, including the functions of memory decision-making", as well as "sense organs, the receiver". In the ten years that followed, Ekman's model developed at least in part out of Ruesch's as, in turn, this psychologist and psychiatrist each increasingly relied upon semiotics. 
After the completion of his internship and graduation, Ekman was conscripted into the army for two years, where he served as "chief psychologist" and conducted "applied studies" (Ekman 2016: 17), working at the Palo Alto Veterans Administration Hospital upon his discharge, before returning to Langley Porter for a postdoctoral fellowship supported by the National Institute of Mental Health (NIMH) from 1961 to 1963. Ekman then received a post-doctoral research grant from NIMH, which started in 1963 and was continuously renewed for the next forty years, in parallel to his professorship in the Department of Psychiatry at the University of California, San Francisco from 1971 to 2004. It was during his postdoc that Ekman began to collaborate with other psychologists, as well as linguists and anthropologists, who principally used semiotic theory. Ekman first met Hungarian-born American semiotician Thomas A. Sebeok, the founder of zoosemiotics and, later, biosemiotics, at the Indiana University Conference on Paralinguistics and Kinesics in Bloomington, Indiana in 1962 (Sebeok 1990: 287).

Over the next twenty years, Sebeok included two papers by Ekman in volumes that he edited in the Approaches to Semiotics and The Semiotic Web book series (Ekman 1978; 1987), and Ekman published four co-authored papers in Semiotica, the journal of the International Association for Semiotic Studies, during Sebeok's tenure as its editor-in-chief (Ekman, Friesen 1969; Ekman, Friesen, Tomkins 1971; Johnson, Ekman, Friesen 1975; Ekman, Friesen, Scherer 1976). In the correspondence between Sebeok and Ekman (Sebeok 1940-2001), ${ }^{2}$ which today is held by the Indiana University Archives, is a letter of reference that Sebeok wrote on 31 August 1976 for the NIMH Research Scientist Award in which he characterizes Ekman as "quite simply the world's leading specialist $[\ldots]$ in communication through nonverbal behavior" and commends how Ekman's methods "give evidence of his mastery of current semiotic theory and psychological technique". Reciprocally, in 1977 Ekman (Sebeok 1940-2001) wrote how he "tremendously value[s] Semiotica" and that it is "by far the best journal in this whole area". In his autobiography, Ekman (2016: 95) even honours Sebeok as "the central figure in the last century promoting the field of semiotics", although he does not further mention the doctrine of signs.

In 1969, Sebeok invited Ekman "to write an article for the first issue" of Semiotica (Ekman 2016: 95). To Ekman (2016: 95-96), this paper, "The repertoire of nonverbal behavior", remains "the seminal theoretical description of [his] approach", with most of what he has "done in the years since an elaboration of what

2 The author would like to thank Mary Mellon, Digital Archivist at the Indiana University Archives, for her assistance in scanning the correspondence between Sebeok and Ekman. These documents are now available online: http://webapp1.dlib.indiana.edu/findingaids/view?doc. view=entire_text\&docId=InU-Ar-VAE0871. 
[he] wrote then, not a replacement". Ekman co-authored the paper with American psychologist Wallace V. (Verne) Friesen, whom he met while serving in the U.S. Army, beginning what would be "twenty-five years of very fruitful collaboration" (Ekman 2016: 37). In this seminal paper, Ekman and Friesen (1969: 49) define "a person's non-verbal behavior" as "any movement or position of the face and/or the body" and describe the "origin, usage, and coding" for this behaviour. According to Ekman and Friesen (1969: 60), coding is the "the principle of correspondence between the act and its meaning" which describes the ways in which the nonverbal act contains or conveys information; that is, the "rule which characterizes the relationship between the act itself and that which it signifies". Ekman and Friesen (1969: 60) identify "three coding principles", namely: nonverbal signs may be "iconically (extrinsically)" coded and "carry the clue to their decoding in their appearance", where "the nonverbal act, the sign, looks in some way like what it means, the significant"; they may be "intrinsically" coded and "like iconically coded behavior" visually relate to what they signify, only where "the act does not stand for but is its significant"; or nonverbal signs may be "arbitrarily (extrinsically)" coded and, "like words", "bear no visual resemblance to what they signify". As shown in Tables 1 and 2 respectively, the terms and definitions for the iconicintrinsic-arbitrary triad in Ekmanian faciasemiotics roughly correspond with the sign-signal-symbol triad in Ruesch's semiotics and, in turn, the icon-index-symbol triad in the Locke-Peirce-Morris tradition.

Table 1. Correspondence between the phenomenological terms of semiotic theories.

\begin{tabular}{llll}
\hline Paul Ekman & Jurgen Ruesch & Charles W. Morris & C. S. Peirce \\
\hline iconic (extrinsic) & sign & icon & icon \\
intrinsic & signal & index & index \\
arbitrary (extrinsic) & symbol & symbol & symbol \\
\hline
\end{tabular}


Table 2. Comparative definitions of iconicity.

\begin{tabular}{ll}
\hline Ekman 1960s & $\begin{array}{l}\text { Iconically-coded signs "carry the clue to their decoding in their } \\
\text { appearance," where "the nonverbal act, the sign, looks in some } \\
\text { way like what it means, the significant" (Ekman, Friesen 1969: } \\
60)\end{array}$ \\
\hline Ruesch 1950s & $\begin{array}{l}\text { Signs constitute "a circumscript part of an action or event which } \\
\text { either by force of its own structure or because of attention paid } \\
\text { to it possesses for an observer problem-solving properties or cue } \\
\text { values" (1972: 127). }\end{array}$ \\
\hline Morris 1940s & $\begin{array}{l}\text { An "iconic sign, it will be recalled, is any sign which is similar in } \\
\text { some respect to what it denotes," such that "the strength of the } \\
\text { iconic sign lies in its ability to present for introspection what it } \\
\text { signifies" (1946: 191, 194). }\end{array}$
\end{tabular}

Peirce late 19th - "An Icon is a sign which refers to the Object that it denotes early 20th C. merely by virtue of character of its own and which it possesses, just the same, whether any such Object actually exists or not," although an icon "does not act [as] a sign," but "anything [...] is an icon of anything, in so far as it is like that thing and used as a sign of it," being "strictly a possibility, involving a possibility, [in which] the Interpretant may be the Object" (EP 2: 291, 2: 227).

In fact, Ekman and Friesen (1969: 60fn4) reference in a footnote how their "use of the term iconic was taken from" American philosopher and semiotician Charles W. Morris. Ekman came to embrace the works of Morris via the works of Ruesch, who does not use the terms 'icon', 'iconic', or 'iconicity' in his taxonomy of signs, but often cites Morris (Ruesch 1972: 93, 299, 344, 500, 559), giving an unequivocal indication of this intellectual genealogy. As Ekman and Friesen quote, Morris characterizes the iconic sign as "any sign which is similar in some respect to what it denotes. Iconicity is thus a matter of degree. [Further,] the strength of the iconic sign lies in its ability to present for introspection what it signifies" (Morris 1946: 191, 194; quoted in Ekman, Friesen 1969: 60 fn4). It is significant that Ekman looked not to Peirce but to Morris for the semiotic foundations of his face science. As Nöth (1990: 49) historicizes, the semiotics of Morris is characterized by a "fundamental departure from the Peircean tradition". Whereas American pragmatist and semiotician Charles Sanders Peirce (CP 2.227, 8.343) conceives the "quasi-necessary, or formal, doctrine of signs" on "logical analysis", Morris (1946: 2) holds the conviction that "a science of signs can be most profitably developed on a biological basis and specifically within the framework of the science of 
behavior". Bringing together behaviourist empiricism, logical positivism, and neopragmatism in a behavioural semiotics that preceded biosemiotics, Morris defines semiosis as a "sign process, that is, a process in which something is a sign to some organism" (Morris 1946: 353). In terms of iconicity, Nöth (1990: 123) identifies, Morris reduced Peirce's multiple criteria for the icon to the single criterion of "shared properties' and believed on this basis in a quantifiability of iconicity".

However, Ekman and Friesen do not only define nonverbal iconicity by the presence of a partial resemblance to the referent, but also by the absence of absolute likeness to this object. That is, Ekman and Friesen (1969: 61) describe how the "iconically coded act is often easier to comprehend and simpler to utilize as a communicative signal; it is more stylized, starker, perhaps more abstract, and will leave out many of the details involved in the intrinsically coded act which it may resemble". In other words, it is the properties of the object (e.g. emotion) that do not determine the construction of the sign (e.g. facial expression) that are revealed through its interrogation in such a way that new information may be derived. Following the tradition of Morris and Ruesch, Ekman and Friesen situate this semiotics within an explicitly biological, communicative, and social framework. Although Ekman and Friesen (1969: 61, 68) state that not many facial signs can be classified cleanly into one coding or another, and that this coding must be based on the predominant function of the facial sign in a given context, the coding in Ekmanian faciasemiotics is principally a hierarchical relation, or a matter of degree on a continuum, in which the intrinsic comes beneath and before the iconic (extrinsic) and the arbitrary (extrinsic).

\section{Giving the semiotic modelling of face a hand}

In addition to these works by Ruesch and Morris, Ekman and Friesen's early semiotic model for facial behaviour "owe[d] most to the writings" of Argentinian anthropologist David Efron (Ekman, Friesen 1969: 63). As Ekman (2016: 10) recalls in his autobiography, Efron studied under German-born anthropologist Franz Boas, the so-called father of American anthropology, who "urged his students to challenge the writings of the Nazi-influenced German social scientists during the 1930s", including the fallacious argument that nonverbal behaviour is genetically determined, and thereby makes visible racial difference, "scientifically" justifying the eugenics programme of the Nazis against the Jews. For his doctoral dissertation Gesture and Environment in 1941, republished as Gesture, Race and Culture in 1972 also in Sebeok's Approaches to Semiotics series, Efron (1972[1941]: 6) conducted quantitative observational studies of what he calls the "gestural styles" 
of East-European Jews and Southern Italians in New York. Efron (1972[1941]: 16, 136) claims that the racist ideology of Nazi Germany is "plagued with conceptions that have no place in scientific reasoning" and concludes that "traditional Jewish and Italian gestures disappear with the social assimilation of the individual into the so-called Americanized community", thus confronting the biological determinism of Nazi ideology by confirming the socio-ecological construction of gestural repertoires. As Ekman (2016: 10) reflects, the "publication of Efron's book coincided with the U.S. entrance into World War II" and, consequently, this "great work was lost [and] rarely cited". However, "building on Efron's work", Ekman (2016: 37) "developed a classification" of nonverbal behaviour, which included gestural behaviour as well as facial behaviour.

For this semiotics of the face, Ekman and Friesen (1969: 63) further drew upon "a series of discussions" with American psychologist George F. Mahl in which they "attempted to clarify some of the issues implicit in his dichotomization of nonverbal behavior". In a study of psychiatric outpatients during initial clinical assessments, Mahl (1987[1968]: 15) categorizes nonverbal behaviour into "actions judged to be common substitutions for verbal utterances" and those "judged not to be" so, or "communicative gestures" such as nodding, pointing, or shrugging, and "autistic actions" such as scratching, rubbing, or touching oneself. Ekman and Friesen (1969: 57) believe that "Mahl's distinction between autistic and communicative behavior, while valuable, can be improved upon", that this "use of the term 'communicative' is too broad," and that communication should distinguish among "behavior which has a shared decoded meaning (informative), that which influences the other person's interaction (interactive)", and, as Mahl had in mind, "that which [is] intended to transmit a message (communicative)". Seeking input on "films of psychiatric patients", Ekman visited Mahl during his fellowship from 1963 to 1964 at what today is known as the Center for Advanced Study in the Behavioral Sciences at Stanford University. As Ekman (2016: 37) writes in his autobiography, Mahl suggested that he focus on the patients' nonverbal "acts' and develop a theoretical classification". Ekman (2016: 37) remembers this being "quite a step forward" for him, especially as "a Skinnerian who had been schooled in not imposing theory, in simply just counting what you saw". Indeed, this moment for Ekman marked a shift in his overall epistemology, from bottom-up inductive reasoning to top-down deductive reasoning and from specific observations to general principles, which in turn laid the conceptual groundwork for his early semiotic modelling of facial behaviour.

Proposing a triadic model of iconic, intrinsic, and arbitrary coding, Ekman and Friesen (1969: 61) then proceed to "refine further the ways in which a nonverbal act is related to its significant". Largely utilizing Efron's "terminology 
and distinctions", they classify five different "visual relationships between act and significant", including kinetic, pictorial, pointing, rhythmic, and spatial relationships, as well as five categories that describe the ways in which nonverbal behaviours can be "distinguished by the particulars of usage, origin and coding", including 'adaptors', 'affect displays', 'emblems', 'illustrators', and 'regulators', as well as numerous sub-categories for a system with an indefinite and unfixed number of phenomenological categories which they term 'codes' (Ekman, Friesen 1969: 61, 63, 68). At this point, Ekman and Friesen theorize their typology primarily, but not exclusively, for hand gestures rather than facial behaviours. For instance, they demonstrate the difference between iconic and intrinsic coding, or what would be iconic and indexical in Peircean as well as Morrisian terms, with gestures of the arm, hand, and fingers in aggressive actions which involve visually forming "cut[ting] a person's throat" or a "trigger finger movement" and actually holding a knife or gun (Ekman, Friesen 1969: 61).

Here, the principal distinction between iconic and intrinsic coding is whether the nonverbal behaviour is literally a part of the movement involved in the action. In other words, is the act just being portrayed or is it really being performed, does it "represent" or "reproduce" a human action, where to be iconic it must "resemble but cannot be its significant" (Ekman, Friesen 1969: 70). Ekman and Friesen (1969: 61) admit that the "line between the iconic and intrinsically coded act may appear to be a fuzzy one", especially in the case of a nonverbal behaviour that is "only a part of a total action". In sum, to Ekman and Friesen (1969: 62) rhythmic and spatial relationships between movement and meaning are always iconic, kinetic relationships may be either iconic or intrinsic, and pointing is always intrinsic, but "typically, nonverbal behavior combines elements of more than one code", and the pictorial may include the spatial, the spatial may include the rhythmic, and so on. That is, not many signs clearly fall into one category or another but must be categorized based on their function within a context. For example, as Ekman and Friesen (1969: 68) note, they "are not proposing that the illustrator category is exclusive of the others; assignment of an act into this category depends upon usage in a given instance". Thus, in Ekmanian faciasemiotics, iconization represents sensory experience and visual perception through a formal resemblance between the sign and the object that it refers to in the extralinguistic real world.

Ekman and Friesen (1969: 78) recognize that the "coding of facial affect displays is not at all obvious". Drawing from English naturalist Charles Darwin and his 1872 work titled The Expression of the Emotions in Man and Animals, the principal claim for this semiotic model, which later became known as Basic Emotions Theory (BET), is threefold. Firstly, the facial expression of emotion is prototypical, specified through biology. Secondly, it is universal across cultures. And, thirdly, 
there is a causal link between the outside physiological behaviour of a facial expression and the inside psychological phenomena of an emotion that emanates it; that is, between facial signifier and emotional signified. According to Ekman and Friesen (1969: 71), the so-called "primary affects", such as 'anger', 'disgust', 'fear', 'happiness', 'sadness', and 'surprise', a list that constantly undergoes variation and revision across Ekman's career, as well as all possible "affect blends", activate with the neural appraisal of an "evoking stimulus" and trigger so-called "programs" of response, which are functionally discrete and phylogenetically stable, and include the muscular contraction mechanisms and skin appearance movements of the face. In this view, any variability to innate expression is largely determined by social scripts or "display rules", which are "socially learned, probably quite early in life, and prescribe different procedures for the management of affect displays in various social setting, roles, etc." (Ekman, Friesen 1969: 75). Therefore, Ekman and Friesen (1969: 74) principally consider what they call "affect 'programs"' to be intrinsically coded, or, in Peircean terms, "a sign which refers to the Object that it denotes by virtue of being really affected by that Object" (EP2: 291-292), where the expressing of the face in an emotion is analogous to the "veering of a weathercock" in the wind (EP2: 274), being the product of this causation.

There is of course much debate in the scientific community over the merits and limitations of BET. Points of criticism encompass, for example, how the theory fails to adequately consider the significance played by context and culture in the facial expression of emotion, the degree to which it is part of social intent, and is not only reactive but also predictive, serving to guide actions. Opposing theories include, for instance, the Behavioural Ecology View and Theory of Constructed Emotion. Ekman (2016: 11, 48, 78) cites Darwin as one of his "intellectual father figures" and claims Darwin's Expression as the foundational text for BET, although Ekman did not read Darwin until quite late in his career. However, in Expression, Darwin (1872: 12, 356) hypothesizes not only that facial expression of emotion "once existed in a much lower and animal-like condition" and consequently may have certain elements of pan-cultural universality, but also that "every true or inherited movement of expression seems to have had some natural and independent origin". Evolved by natural selection, these emotion expressions are either remnants from reflexes that had once been useful, arise from the antithesis of contrasting elicitors, or are the direct action of the nervous system in an overflow of excitation. Darwin $(1872: 67,76)$ concludes that most human facial behaviour is a rudimentary or vestigial feature much like the appendix, body hair, tail bone, or wisdom teeth, which is "of no service, often of much disservice" and "purposeless", with any communicative value being incidental. 
To Ekman and Friesen (1969: 78), “[b]oth Darwin's explanation of the evolution of such displays, and [their own] account of how certain displays may naturally develop in the course of each person's life, would suggest that some affect displays are either intrinsically coded or iconic". However, Ekman and Friesen (1969: 78) concede that this coding may be the case "only for some affects". "[I]f we accept Darwin's principle of antithesis as the explanation of the happiness display," Ekman and Friesen (1969: 78) admit, "then it would be arbitrarily coded". Even so, social psychologist Alan J. Fridlund (2017: 77) argues that Ekman, among other advocates of BET, "misread" Darwin "when they cite him to support their claim that facial expressions evolved 'to express emotion"' and that certain facial expressions are universal. But if the face did not evolve for carrying information and social communication, as Darwin finds, this does not mean that facial expressions would bear no resemblance to the emotions they signify, as Ekman and Friesen suggest; they could still be intrinsically or iconically coded, just on different grounds. Nevertheless, for Ekman and Friesen (1969: 60 n5) the "recognition of the need to distinguish intrinsically coded from iconic behavior grew out of a discussion" with American psychologist Silvan S. (Solomon) Tomkins, who had modelled a universalist primary affect theory in the first two volumes of his magnum opus, Affect Imagery Consciousness in 1962 and 1963. In Ekmanian faciasemiotics, the distinction between the iconic or arbitrary and the intrinsic is crucial in determining whether a facial event is a voluntary, staged, and posed expression that accompanies intentional communication, or an involuntary, spontaneous, and genuine expression that accompanies felt emotion.

This semiotic model of facial behaviour is highly problematic on methodological as well as theoretical levels. Of course, there are different approaches to modelling nonverbal behaviour across the academic disciplines, including coding systems that classify the alteration, description, or function of behaviour, which today are more and more based not only on anatomy but also on neuroanatomy. As critiqued by neurologist Hedda Lausberg (2013: 65), creator of the Neuropsychological Gesture Coding System (NEUROGES), Ekman and Friesen define their "main values" for "the analysis of movement behavior in social interaction" as "predominantly functional", with adaptors, affect displays, emblems, illustrators, and regulators all theorized in connection with a certain psychodynamic. However, some of these "main values contain several movement classes", such as how "regulators can be positions shifts but also head nods", and, additionally, the values "may all function as regulators" (Lausberg 2013: 65). Consequently, "there is no precise definition referring to the visual appearance of the movement" (Lausberg 2013: 65).

Ultimately, Ekman also came to recognize this methodological problem, both in "14 techniques for measuring facial actions [over] a span of 55 years" between 1924 
and 1978 (Ekman 1982: 50), including anatomically, ethologically, linguistically, and theoretically based systems, as well as his own Facial Affect Scoring Technique (FAST), a precursor to FACS (Ekman, Friesen, Tomkins 1971). Psychologist Erika Rosenberg, who worked on FACS with Ekman in his Human Interaction Laboratory at the University of California, San Francisco from 1991 to 1994, and who now instructs how to code the face in her FACS Workshop, points out that the "problem with theoretically derived systems is that they cannot discover behaviors that were not posited in advance" and are "by definition selective"; in other words, these coding systems "were not developed to catalogue everything the face can do, but rather they describe whether the face does things it should do according to a given theory" (Rosenberg 2005[1997]: 14). ${ }^{3}$ Having begun his search for facial iconicity with the works of Ruesch, Efron, Mahl, Sebeok, and Tomkins, among others, Ekman (1982: 46) turns from theorizing a semiotic model to developing a measurement tool, one which can be used for "measuring the sign vehicles that convey the message" rather than making interpretation "judgments about one or another message", and for classifying "descriptive units" rather than "inferential labels".

\section{Analogue privilege, digital process}

In their seminal paper, Ekman and Friesen (1969: 60n4) also cite how their distinction between iconic and arbitrary coding is "very similar" to Ruesch's distinction between analogue and digital codification. To Ruesch (1972: 131), "analogic codification makes use of continuous representations", whereby "the signs used are, in their proportions and relations, similar to the things, ideas or events for which they stand", while "digital codification, in contrast, is based upon discontinuous representation of events in which the continuity of nature is sliced into discrete steps". Of course, Ekman and Friesen (1969: 60fn4) make clear that when they write about the terms 'analogic' and 'digital', they do not mean these as media per se, or to "involve further specifications of the mathematics relevant to modelling information processing" from computer or electronic technologies, in the sense of the terms already being used in the 1960s and most frequently applied today. Rather, working from Ruesch's definition, Ekman and Friesen (1969: 60n4) go on to claim that the iconic-analogue is fundamentally "more characteristic of nonverbal behavior" such as facial behaviour while the arbitrary-digital is fundamentally more characteristic of verbal behaviour such as spoken language.

3 For transparency of interest, the author participated in the FACS Workshop with Rosenberg at the University of California, Berkeley in 2015 and the NEUROGES seminar with Lausberg at the German Sports University Cologne in 2017. 
This contrast between the analogic and the digital in Ekmanian faciasemiotics is overall consistent with semiotic theory. As Daniel Chandler (2017: 183) surveys the field, semioticians tend to regard analogue codes as distinctions of degree, a relation of more-or-less, signs which are natural, implicit, as well as continuous, that is, a gradation of infinite subtleties; digital codes as distinctions of kind, a relation of either/or, signs which are artificial, explicit, as well as discontinuous, that is, a categorization of discrete units; and communication as something that "involves both modes". This distinction between analogue and digital codes, Chandler (2017: 184) explicates, is "frequently represented as natural versus artificial", extending an argument made by Claude Lévi-Strauss about the isomorphism between oppositions: that of nature and culture and that of continuous and discrete. Yet such a distinction, which has underlain the faciasemiotic project since classical physiognomy, carries with it an entire host of dyadic connotations, such as contrasting the emotional work of the flesh against the rational work of the mind and, consequently, facial behaviour against spoken language, with the connotation being that it is the outer physiological form that most accurately reflects the inner psychological function.

In Ekmanian faciasemiotics, the signs of the face are considered more genuine and truthful, and consequently of higher value, when compared with the signs of spoken, thought, or written language. This can especially be seen in Ekman's research into deception detection. For instance, Ekman and Friesen (1969: 88, 93) refer to the concealed or repressed affect displayed in "[m]icro' facial expressions" with comparatively short duration as "nonverbal leakage". And psychologist Maureen O'Sullivan and Ekman (2004: 275) refer to individuals who achieve 80\% accuracy identifying deception in facial behaviour as 'expert' lie detectors or [truth] 'wizards". Behind this nomenclature is the perspective that intrinsic facial signs are not only analogic but also natural and that iconic as well as arbitrary facial signs are not only digital but also artificial.

In his 1978 paper "Facial signs", Ekman (1978: 141, 151fn9) reflects on how he has "argued that the linkage between facial movement (sign) and emotion (significant) is natural [...] rather than a conventional or arbitrary association," noting that he uses "the term natural as it has been discussed and defined by Sebeok". To Sebeok (1975: 237, 239), both signals and symptoms exemplify natural signs, as a signal "triggers some reaction on the part of the receiver" either "mechanically (i.e., naturally) or conventionally (artificially)", and a symptom is a "compulsive, automatic, nonarbitrary sign, such that the signifier is coupled with the signified in the manner of a natural link". Whereas Ekman singles out the naturality of indexicality, or what he terms intrinsicality, Sebeok $(1975: 242,247)$ explains how iconic and indexical sign relations have a natural link, whereas symbolic sign relations have a "conventional link' - Peirce's 'imputed character"'. 
Drawing from Sebeok, Ekman (1978: 141) claims that his "view of facial expression has been based on the assumption that if facial expressions are evolved behavior", and "if the relationship between sign and significant is natural", then facial expressions of emotion must also be "impervious to the influence of culture". However, Ekman (1978: 141) clarifies, he has "never said that facial expressions are always automatic or unwitting. Facial expressions of emotion are not fixed-action patterns or instincts of some kind, impervious to culture. They can be automatic, but not always or even usually". To Ekman, the intrinsic face, that is, the indexical face, is the rare face in the endless forms most beautiful of human communication. Yet, regarding the value of the icon, like in Peircean semiotics, these picture-like signs resemble the object that they signify, have the modality of direct, immediate perception, and are therefore the most persuasive of signs.

While Ekman privileges analogue signs in his semiotic model of facial behaviour, digital sign processes are important and even necessary for the development of his Facial Action Coding System. In the ten years between 1969 and 1977, Ekman and his research team in the Human Interaction Laboratory at the University of California, San Francisco developed the Facial Action Coding System, released in 1978 and revised in 2002. FACS is a "comprehensive" sign-based technique for the description, measurement, and classification of "all possible visually distinguishable facial movements" (Ekman, Friesen 1976: 58). This coding system is based at least in part on work of French neurologist Guillaume Duchenne and Swedish anatomist Carl-Herman Hjortsjö, among others (Ekman, Friesen 1976: 63). Applying FACS, Ekman and Friesen (1976: 64) instruct, a coder scores individual Action Units (AUs) that have an "anatomical basis" but do not necessarily correspond one-to-one to either specific muscles or muscle groups. FACS supports the performance of a spatial analysis of the face, both globally with principal components, as well as locally with particular features, with the use of intensity scores for each Action Unit which are annotated by appending letters (A-E) from trace or very slight (A) to maximal or strongest possible (E). FACS also supports the performance of a temporal analysis of the face through the observation and measurement of the combination of Action Units, or what is commonly meant by an expression, with the use of timing scores which segment the actions into their "onset, apex, and offset" (Ekman, Friesen 1976: 60). For instance, in what is popularly known as the smile of happiness, the zygomatic major constricts posteriorly and superiorly, pulling the lip corners upwards, and the orbicularis oculi, pars lateralis constricts laterally, raising the infraorbital triangle, lifting the cheeks, and gathering the skin medially toward the eye socket from around its lateral edge. As Fig. 1 illustrates, the combination of these facial actions in FACS is described using Action Unit 6, the "Cheek Raiser", and Action Unit 
12, the "Lip Corner Puller" (Ekman, Friesen 1976: 65), or, with the lips apart and mouth open, and attendant intensity ratings, and $6 \mathrm{D}+12 \mathrm{E}+25 \mathrm{C}$.

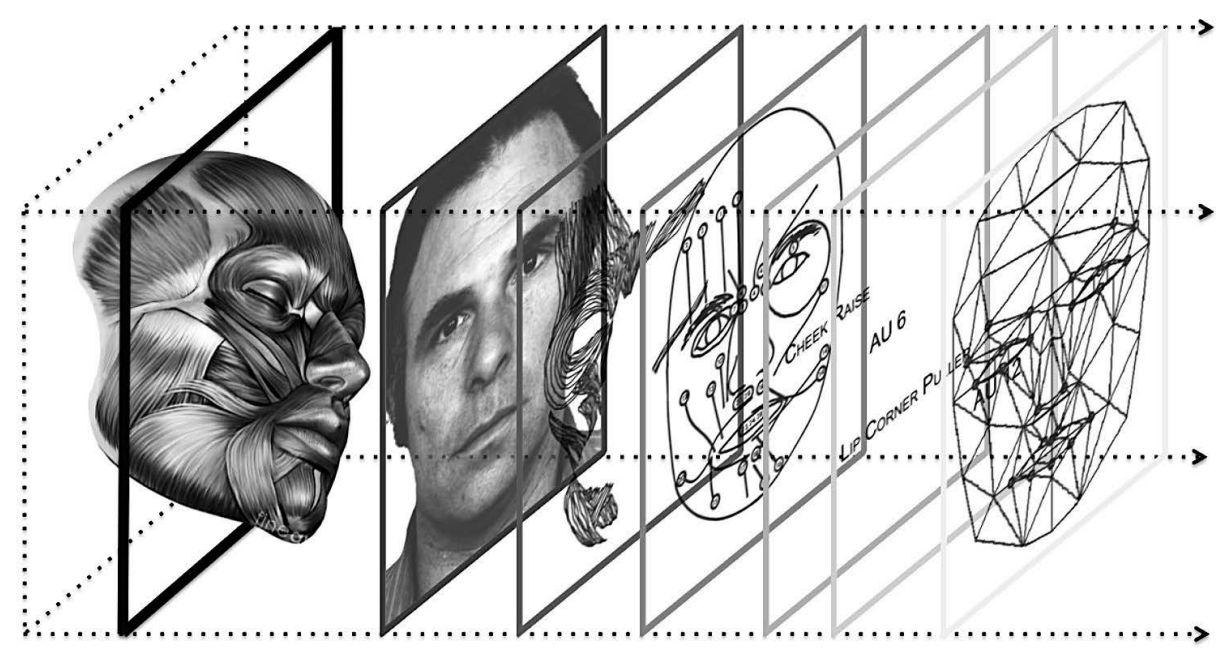

Figure 1. Onto-cartographic projection in four-dimensions (4D), three dimensions of space (width, depth, and height) and one dimension of time, representing the iconic continuum of facial signs.

This "digitization" of the face has led to a common misconception in expert scholarship and popular culture: that in Ekmanian faciasemiotics, facial behaviour is understood as a linguistic system, one in which muscular contraction mechanisms form up alphabetic elements, and skin appearance movements function like grammatical morphemes, whereby the face speaks or writes emotion which in turn can be heard or read by a face-literate expert coder. For instance, "Ekman is Saussurean," Jeremy Sherman commented to me in at the Annual Gathering in Biosemiotics at Lomonosov Moscow State University in 2019. The unspoken implication was not that Ekman follows Saussure through his bibliographic references, but rather that Ekmanian faciasemiotics resembles Saussurean linguistics. As Swiss linguist and semiotician Ferdinand de Saussure (2006: 140) writes, "[1] anguage represents a system internally ordered in all its parts", which "depends on an object, but free and arbitrary in relation to the object". Further, according to Saussure (2006: 147), "language and writing are NOT BASED on a natural relationship between things," and there is "never in any way a link" between the signifier and signified. 
Certainly, Ekman and Friesen (1976: 64, 65fn) note, for the Action Units of the Facial Action Coding System, the names are a "shorthand, not meant to describe the appearance changes, but a convenience to call them to mind," and the "numbers are arbitrary and do not have any significance". Yet this application of digital signs in the study of the face is not the same as alleging that facial behaviour is itself a language. Nevertheless, the popular myth that in Ekmanian faciasemiotics the face is viewed as a text is widely propagated, for instance in Lie to Me, the 2009-2011 television drama series based on Ekman's life and works, which carries the tagline "The truth is written all over our faces". However, to claim that facial behaviour meets some linguistic benchmark would be to confuse digital with linguistic signs. "[A]nalogue signs can of course be digitally reproduced," Chandler (2017: 185) explains, "but they cannot be directly related to a standard 'dictionary' and syntax in the way that linguistic signs can”. As Ekman (1978: 151fn9) writes in his own words, it is "important not to misread [his] use of the terminology of semiotics as an implication that the facial signs are a linguistic system".

Nevertheless, the foundational process for Ekmanian faciasemiotics is the intersemiotic translation from the analogue signs of certain facial behaviours to the digital signs of the Facial Action Coding System. Still, as Chandler (2017: 184) points out, all sign systems "impose digital order on what we often experience as a dynamic and seamless flux", and the "very definition of something as a sign involves reducing the continuous to the discrete". Structuralists including Saussure, Lévi-Strauss, and Roman Jakobson even theorize about how the process of making differentiations and the mere otherness of either/or oppositions is fundamental not only to linguistic systems in particular but also to signifying systems in general. Across his career, Ekman described the facial expression of emotion using objectivity and rationality, both in the 1960s with his use of affect display gestalts, since the 1970s with his use of minimal Action Units, as well as since the 1980s with the selective application of AUs to gestalts for stereotypical emotions, as with EmotionFACS (EMFACS). However, this was not because he observed these facial behaviours to be this way amid the phenomena of the world; rather, it was because Ekman experimented on facial signs in such a way amid the processes of his study. That is, the definition for the facial expression of emotion in Ekmanian faciasemiotics has been altered to fit a particular conception of what science ought to be in order to make it practisable. 


\section{Conclusion}

The question of whether or to what extent facial behaviour may be indexical is by no means resolved, either in Ekman's oeuvre or the face sciences. In the neuro-cultural model of Ekmanian faciasemiotics, facial signs may be "iconically (extrinsically), intrinsically, or arbitrarily (extrinsically) coded" (Ekman, Friesen 1969: 60), which is to say, iconically, indexically, or symbolically coded in terms deriving from the Locke-Peirce-Morris tradition, on the basis of the visual appearance of the dynamic movement, either in whole or in part, and depending on the predominant function of the nonverbal behaviour in the given context. In this view, the facial expression of emotion is most likely "either intrinsically coded or iconic" (Ekman, Friesen 1969: 78). However, the distinction between these codes is a "fuzzy one" and the way to determine this principle of correspondence between the act and its meaning, the signifier and its signified, is "not at all obvious" (Ekman, Friesen 1969: 61, 78).

Further, if the neuroanatomy of the face did not evolve at least to some degree for carrying information about emotion phenomena, whether on the intra- or inter-organismic level, then the facial expression of emotion "would be arbitrarily coded" (Ekman, Friesen 1969: 78). In other words, as Umberto Eco argues, "spontaneous, noncodified expressions of emotion produced without any communicative intention" may well fall "below the semiotic threshold", and only "become codified and thus semiotic" when they "exhibit cultural variation or are simulated or imitated in a histrionic context" (Eco cited in Nöth 2000: 54). For Ekman, however, there is an important "recognition of the need to distinguish intrinsically coded from iconic behavior" (Ekman, Friesen 1969: 60fn5). In Ekman's terms, iconic and arbitrary coding, each of which are extrinsic codes, and not entirely part of the essential nature of the nonverbal behaviour, but also operate with or arise from the outside, and "signifies or stands for something else", whereas intrinsic coding "is in a sense no code in that the act does not stand for but is its significant; the meaning of the act is intrinsic to the action itself" (Ekman, Friesen 1969: 60). Additionally, this distinction means differentiating the analogic and natural signifying relation of intrinsic codes from the digital and artificial signifying relation of iconic and arbitrary codes. As Ekman (1978: 141) argues, "the relationship between sign and significant is natural" in certain facial expressions of emotion, and thereby "automatic or unwitting" and "impervious to the influence of culture", but facial behaviour is "not always or even usually" this way.

Ekman's science, as Jan Plamper (2015: 155) historicizes, "involved the reconciliation of nature (basic emotion) and culture (display rule)". And as Ruth Leys (2017: 90) contextualizes, "Ekman was committed to the project of distinguishing 
between nature and culture, between the 'natural signs' of emotional expression that might be so small or rapid as to be easily overlooked and those culturally coded displays or 'artificial signs' that he thought tended to mask or disguise them". Thus, in Ekman's faciasemiotic project, beneath the exclusively arbitrary coding that is entirely culturally assigned, the indexical face really performs the emotion, intrinsically representing a part of the movement involved in this action, such as with the "enjoyment smile", whereas the iconic faceness just portrays the emotion, extrinsically resembling the action only in some respect, such as with the so-called "false", "masking", and other non-enjoyment smiles (Ekman, Davidson, Friesen et al. 1990: 342-343). This is exactly why iconicity is so essential in the early faciasemiotics of Paul Ekman: by lying, iconic facial signs provide clues to the truth, that is to say, the truthfulness of the indexical.

\section{References}

Berson, Josh 2015. Computable Bodies: Instrumented Life and the Human Semiotic Niche. London: Bloomsbury.

Bouissac, Paul 2007[1998]. Encyclopedia of Semiotics. Oxford: Oxford University Press. Chandler, Daniel 2017[2002]. Semiotics: The Basics. (3rd ed.) London: Routledge.

CP $=$ Peirce, Charles S. 1931-1958. Collected Papers of Charles Sanders Peirce. Cambridge:

Harvard University Press. (Vols. 1-6, Hartshorne, Charles; Weiss, Paul, eds.; vols. 7-8, Burks, Arthur Walter, ed.) [In-text references are to CP, followed by volume and paragraph numbers.]

Darwin, Charles 1872. The Expression of the Emotions in Man and Animals. London: John Murray. https://doi.org/10.1037/10001-000

Efron, David 1972[1941]. Gesture, Race and Culture: A Tentative Study of the Spatiotemporal and "Linguistic" Aspects of the Gestural Behavior of Eastern Jews and Southern Italians in New York City, Living Under Similar as Well as Different Environmental Conditions. (Approaches to Semiotics 9.) The Hague: Mouton.

Ekman, Paul 1957. A methodological discussion of nonverbal behavior. The Journal of Psychology 43(1): 141-149. https://doi.org/10.1080/00223980.1957.9713059

Ekman, Paul 1978. Facial signs: Facts, fantasies, and possibilities. In: Sebeok, Thomas A.

(ed.), Sight, Sound and Sense: Advances in Semiotics. Bloomington: University of Indiana Press, 124-156.

Ekman, Paul 1982. Methods for measuring facial action. In: Scherer, Klaus R.; Ekman, Paul (eds.), Handbook of Methods in Nonverbal Behavior Research. Cambridge: Cambridge University Press, 45-135.

Ekman, Paul 1987. A life's pursuit. In: Sebeok, Thomas A.; Umiker-Sebeok, Jean (eds.), The Semiotic Web '86: An International Yearbook. Berlin: Mouton de Gruyter, 3-45.

Ekman, Paul 2016. Nonverbal Messages: Cracking the Code - My Life's Pursuit. San Francisco:

Paul Ekman Group. 
Ekman, Paul; Davidson, Richard J.; Friesen, Wallace V. 1990. The Duchenne smile: Emotional expression and brain physiology II. Journal of Personality and Social Psychology 58(2): 342-253. https://doi.org/10.1037/0022-3514.58.2.342

Ekman, Paul; Friesen, Wallace V. 1969. The repertoire of nonverbal behavior: Categories, origins, usage, and coding. Semiotica 1(1): 49-98. https://doi.org/10.1515/ semi.1969.1.1.49

Ekman, Paul; Friesen, Wallace V. 1976. Measuring facial movement. Environmental Psychology and Nonverbal Behavior 1(1): 56-75. https://doi.org/10.1007/BF01115465

Ekman, Paul; Friesen, Wallace V.; Scherer, Klaus R. 1976. Body movement and voice pitch in deceptive interaction. Semiotica 16(1): 23-27. https://doi.org/10.1515/ semi.1976.16.1.23

Ekman, Paul; Friesen, Wallace V.; Tomkins, Silvan S. 1971. Facial affect scoring technique (FAST): A first validity study. Semiotica 3(1): 37-58. https://doi.org/10.1515/ semi.1971.3.1.37

EP = Peirce, Charles S. 1992. The Essential Peirce: Selected Philosophical Writings. Bloomington: Indiana University Press. (Vol. 1, Houser, Nathan; Kloesel, Christian, eds.; vol. 2, Peirce Edition Project, ed.) [In-text references are to EP, followed by volume and page numbers.]

Fridlund, Alan J. 2017. The behavioral ecology view of facial displays, 25 years later. In: Fernández-Dols, José-Miguel; Russell, James A. (eds.), Oxford Series in Social Cognition and Social Neuroscience: The Science of Facial Expression. New York: Oxford University Press, 77-92. https://doi.org/10.1093/acprof:oso/9780190613501.003.0005

Gendron, Maria; Barrett, Lisa Feldman 2017. Facing the past: A history of the face in psychological research on emotion perception. In: Fernández-Dols, José-Miguel; Russell, James A. (eds.), Oxford Series in Social Cognition and Social Neuroscience: The Science of Facial Expression. New York: Oxford University Press, 15-38.

Grammer, Karl 2004. Körpersignale in menschlicher Interaktion. In: Posner, Roland; Robering, Klaus; Sebeok, Thomas A. (eds.), Semiotik: Ein Handbuch zu den zeichentheoretischen Grundlagen von Natur und Kultur. 4. Teilband. Berlin, New York: Walter de Gruyter, 3448-3486. https://doi.org/10.1515/9783110179620.4.15.3448

Johnson, Harold G.; Ekman, Paul; Friesen, Wallace V. 1975. Communicative body movements: American emblems. Semiotica 15(4): 335-353. https://doi.org/10.1515/ semi.1975.15.4.335

Lausberg, Hedda (ed.) 2013. Understanding Body Movement: A Guide to Empirical Research on Nonverbal Behaviour: With an Introduction to the NEUROGES Coding System. Frankfurt: Peter Lang.

Leys, Ruth 2017. The Ascent of Affect: Genealogy and Critique. Chicago: University of Chicago Press. https://doi.org/10.7208/chicago/9780226488738.001.0001

Mahl, George F. 1987[1968]. Gestures and body movements in interviews. In: Mahl, George F., Explorations in Nonverbal and Vocal Behavior. Hillsdale: Lawrence Erlbaum Associates, 7-74.

Morris, Charles W. 1946. Signs, Language, and Behavior. New York: Prentice-Hall. https:// doi.org/10.1037/14607-000

Nöth, Winfried 1990. Handbook of Semiotics. Bloomington: Indiana University Press. https://doi.org/10.2307/j.ctv14npk46 
Nöth, Winfried 2000. Umberto Eco's semiotic threshold. Sign Systems Studies 28(1): 49-61. https://doi.org/10.12697/SSS.2000.28.03

O'Sullivan, Maureen; Ekman, Paul 2004. The wizards of deception detection. In: Granhag, Pär Anders; Strömwall, Leif A. (eds.), The Detection of Deception in Forensic Contexts. New York: Cambridge University Press, 269-286. https://doi.org/10.1017/ CBO9780511490071.012

Plamper, Jan 2015. The History of Emotions: An Introduction. (Tribe, Keith, trans.) Oxford: Oxford University Press.

Rosenberg, Erika L. 2005[1997]. The study of spontaneous facial expressions in psychology. In: Ekman, Paul; Rosenberg, Erika L. (eds.), What the Face Reveals: Basic and Applied. Studies of Spontaneous Expression Using the Facial Action Coding System (FACS). (2nd ed.) Oxford: Oxford University Press, 3-18. https://doi.org/10.1093/ acprof:oso/9780195179644.003.0001

Ruesch, Jurgen 1972. Semiotic Approaches to Human Relations. (Approaches to Semiotics 25.) The Hague: Mouton. https://doi.org/10.1515/9783110816228

Saussure, Ferdinand de 2006. Writings in General Linguistics. (Bouquet, Simon; Engler, Rudolf, eds.; Sanders, Carol; Pires, Matthew, trans.) Oxford: Oxford University Press.

Sebeok, Thomas A. 1940-2001. Thomas Sebeok papers, correspondence and subject files.

Collection C264, Boxes 26, 27, 61. Bloomington: Indiana University Archives.

Sebeok, Thomas A. 1975. The semiotic web: A chronicle of prejudices. Bulletin of Literary Semiotics 2: 1-63. https://doi.org/10.5840/bls197521

Sebeok, Thomas A. 1990. Semiotics in the United States. In: Sebeok, Thomas A.; UmikerSebeok, Jean (eds.), The Semiotic Web 1989. Berlin: Walter de Gruyter, 275-396. https:// doi.org/10.1515/9783110874099

\section{Лицо и лицевость: иконичность в ранней лицосемиотике Пола Экмана, 1957-1978}

Пол Экман - американский психолог, ставший пионером изучения поведения лица. Статья посвящена ранним исследованиям Экмана в 1957-1978 годах и объединяет историю дисциплины, биографию и историю науки.

Я рассматриваю, как развивалась семиотическая модель поведения Экмана, и прослеживаю проявления иконичности в его жизни и работе: от иконического кодирования быстрых знаков; через поворот от классификации режимов знакового обозначения с использованием категорий гештальта к классификации режимов создания знаковых функций с использованием минимальных единиц; к роли и важности иконичности для изучения выражения эмоций на лице с точки зрения как сходства между знаковыми и аналоговыми признаками, так и различий между кодированием лица и лингвистическим обозначением. В этой интеллектуальной генеалогии я утверждаю не только, что Экман в значительной степени полагался на концептуализацию и терминологию семиотики при создании Системы кодирования лицевых движений (FACS), но также что проблема иконичности лежит в основе многих открытий и инноваций, которые я называю «лицосемиотикой Экмана». 


\section{Nägu ja näolisus: ikoonilisus Paul Ekmani varases näosemiootikas,}

\section{7-1978}

Paul Ekman on Ameerika psühholoog, kes pani aluse näokäitumise uurimisele. Artiklis liidetakse eriala ajalugu, eluloouuringud ning teaduslugu, keskendudes Ekmani varajasele teadustegevusele kakskümmend aastat kestnud perioodil vahemikus 1957 kuni 1978. Selgitan Ekmani loodud näokäitumise semiootilise mudeli ajaloolist arengut, järgides ikoonilisuse juhtlõnga tema elus ning töödes alates kiirete märkide ikoonilisest kodeerimisest, läbi viimaks toimunud pöörde ikoonilise tähistamise laadide klassifitseerimiselt gestaltkategooriaid kasutades ikooniliste märgifunktsioonide tekitamise klassifitseerimisele minimaalseid üksuseid kasutades; kuni ikoonilisuse rolli ning tähtsuseni emotsionaalsete näoilmete uurimises, nii ikoonliste ja analoogmärkide sarnasuste terminites kui ka näolise kodeerimise ja keelelise tähistamise erinevuste kaudu. Väidan, et selles intellektuaalses genealoogias Ekman mitte üksnes ei toetunud näotegevuse kodeerimissüsteemi (FACSsüsteemi) luues ulatuslikult semiootilisest mõtlemisest pärinevatele kontseptualiseeringutele ja terminoloogiale, vaid lisaks on ikoonilisuse küsimus pöördelise tähtusesega probleem arvukates avastustes ja uuendustes valdkonnas, mida ma nimetan "ekmanlikuks näosemiootikaks". 